\title{
Research of the modernized intake system of the gasoline engine
}

\author{
Mahats M. I. ${ }^{1}$, Hoshko Z. O. ${ }^{1}$, Vahula Y. I. ${ }^{1}$, Uzhva A. V. ${ }^{2}$ \\ ${ }^{1}$ Lviv National Agrarian University \\ ${ }^{2}$ Kharkiv National Automobile and Highway University, Ukraine
}

\begin{abstract}
Problem. In recent years, Ukraine has seen a sharp decline in ambient temperature, especially in the winter. Accordingly, this has a negative impact on the performance of car engines (difficult to start and prolonged warm-up), as the lion's share of private sector cars are parked in open areas and are subject to sudden temperature and humidity changes. Therefore, to partially solve this problem, our attention was focused on the air lines of the intake system of the gasoline engine, as this system is easily accessible and does not require significant design changes for its modernization. Goal. The purpose of the work is to ensure the ease of starting the gasoline engine and reduce the time to warm up. Methodology. Operation of the car in the conditions of the lowered temperatures, essentially promotes deterioration of its fuel economy. The basis of such a negative process of fuel consumption is incomplete combustion of the working mixture. And this is the deterioration of spraying and evaporation of fuel and increasing the duration of engine warm-up. At such low ambient temperatures, the effective operation of the car in a garage depends significantly on the method of its preparation (which should at a minimum cost of fuel and energy resources to ensure rapid and reliable engine start and accelerated warm-up). We decided to obtain thermal energy to heat the inlet air at no additional cost. This is the installation of a gasoline engine with a spark ignition of the incandescent coil in the intake air line, which will receive power from the battery. Such modernization of the system does not require major design changes and significant financial investments Unresolved issues remain to assess the effectiveness of the process of heating the air entering the combustion chamber of the engine to create a working mixture. It should be noted that the optimal heating of the engines is most appropriate to carry out (ie heating the coolant and oil in the engine lubrication system) not to the temperature of the operating thermal mode, but to the temperature that ensures its reliable start. Results. The scheme of connection of a heater of intake air in an onboard electric network of the car is presented. The results of the heat balance of the studied gasoline engine (using cold and heated air flow) during its heating are obtained. The optimum temperature of the warmed-up engine at which further economical operation of the car is possible is established. Originality. This spiral heater was first used to heat the intake air charge during the start-up and warm-up of a gasoline engine. Practical value. The developed heating equipment can be used for both gasoline and diesel internal combustion engines. It should be switched on only during engine start-up and warm-up.
\end{abstract}

Key words: glowing filament, intake system, starting characteristics, engine warm-up time, fuel consumption.

\section{Introduction}

In recent years, Ukraine has seen a sharp decline in ambient temperature, especially in the winter. Accordingly, this has a negative impact on the performance of car engines (difficult to start and prolonged warm-up) [1], as the lion's share of private sector cars are in open areas and are subject to sudden temperature and humidity changes.
Therefore, to partially solve this problem, our attention was focused on the air lines of the intake system of the gasoline engine, as this system is easily accessible and does not require significant design changes for its modernization.

\section{Analysis of publications}

The quality of mixing air with fuel and air temperature, significantly affect the performance of 
the engine (especially fuel efficiency, environmental friendliness, power, starting properties and wear intensity of parts) [2-4].

Under different operating conditions of cars, it is necessary to provide the optimal thermal mode of operation of the internal combustion engine from $+40^{\circ} \mathrm{C}$ to $+95^{\circ} \mathrm{C}$. These conditions are violated by the low ambient temperature and the quality of mixing of air and fuel flows, forming a working mixture that enters the working cylinders of the engine. Scientists have proved that increasing the wind speed to $12 \mathrm{~m} / \mathrm{s}$ - leads to an increase in the cooling process of the engine elements by about 3 times compared to the static state of the car $[5,6]$.

Adverse starting properties of a cold gasoline engine, due to the difficulty of achieving the required speed of the crankshaft - are interpreted as the deterioration of the conditions of formation (preparation) of a quality working mixture. Engineers - researchers have proved that the start of a new gasoline engine is achieved when the crankshaft speed reaches $40 \ldots 50 \mathrm{rpm}$. Then, the engine power system is able to provide the necessary process of preparation of the fuel-air mixture for ignition [7].

As a result, the lion's share of the minimum crankshaft speed (during start-up) depends on the ambient temperature and the availability of additional equipment for the pre-start thermal system of the cold engine, engine design and its serviceability.

The moment of resistance to the starter acts on the compression of the fuel-air mixture and on overcoming the forces of inertia, which does not actually change, but the change in air temperature at the time of overcoming friction forces (from 0 to minus $20^{\circ} \mathrm{C}$ ) changes 4 times. This change in the resistance force is due to the increase in oil viscosity in the engine lubrication system. Another component of the energy balance of the internal combustion engine is the chemical energy of the fuel. It affects the overcoming of the forces of friction and inertia of the masses of the crank mechanism [8-9].

Scientific staff has proven that a significant part of thermal energy after combustion of the working mixture is lost with the exhaust gases. These costs increase significantly with changes in temperature between the engine and the environment.

Graphically, the energy balance of the gasoline internal combustion engine in the heating mode, shown in Fig. 1 (at constant speeds and loads).

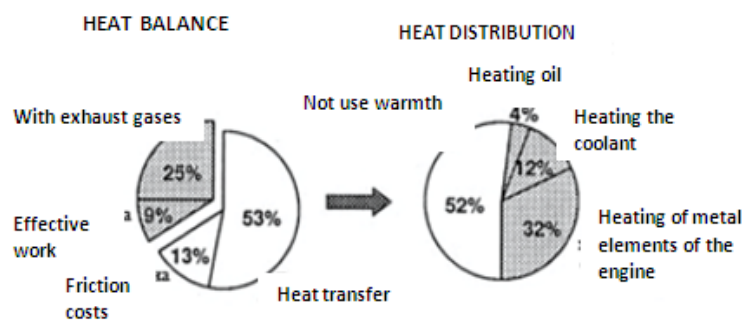

Fig. 1 Energy balance of the engine with spark ignition [10]

From the above diagrams it is seen that the diagram №1 shows the energy of the heat balance (in the combustion chamber of the engine), and under № 2 shows the distribution of thermal energy (for warming up the engine), 53\%. Accordingly, $4 \%$ is spent on heating the oil in the crankcase, $12 \%$ on heating the coolant in the cylinder block, $32 \%$ is spent on heating the metal elements of the engine (cylinder block, cylinder head, crankshaft) and $52 \%$ of heat is absorbed by the environment (ie extra energy costs). Based on these diagrams, it is possible to determine the most optimal ways to solve problems to increase the energy efficiency of the engine (given the reduction of the impact of cold start and its warm-up). And this is the use of various engine insulators and batteries, which is a safeguard to reduce heat loss to the environment. During the start-up of the cold engine, the process of wear of the surfaces of the slidercrank linkage parts is intensive. Such an aggressive environment occurs due to condensation of parts of the fuel that falls on the cold walls of the cylinders. Under the influence of mechanical loads and chemically aggressive environment, the oil film on the friction surfaces of conjugated parts is intensively destroyed. It is proved that at the temperature of the coolant up to $+40^{\circ} \mathrm{C}$, the wear rate of the cylinder liners increases 4 times, and at the temperature $+50^{\circ} \mathrm{C} 2$ times $[11,13]$.

Summarizing the above, it can be stated that in the process of starting and warming up the gasoline engine, the process of mixing and oxidation of the hydrocarbon mass with the air supplied by the engine intake system is not complete.

Therefore, all this determines the urgency of developing equipment that would provide improved conditions for mixing fuel with air in the combustion chambers, and further contribute to the improved start of the gasoline engine at subzero ambient temperatures. 


\section{Purpose and Tasks}

Therefore, it is necessary to modernize the intake system of the gasoline engine and improve the quality of preparation of the working mixture in the cylinders. Determine the dependence of engine warm-up time and fuel consumption on the temperature of the intake air charge.

Accordingly, the aim of our research is to improve the starting characteristics and reduce the warm-up time of the gasoline engine in conditions of low ambient temperatures.

\section{The main material presentation}

Operation of the car in the conditions of the lowered temperatures, essentially promotes deterioration of its fuel economy. The basis of such a negative process of fuel consumption is incomplete combustion of the working mixture. And this is the deterioration of spraying and evaporation of fuel and increasing the duration of engine warm-up. At such low ambient temperatures, the effective operation of the car in a garage depends significantly on the method of its preparation (which should at a minimum cost of fuel and energy resources to ensure rapid and reliable engine start and accelerated warm-up).

We decided to obtain thermal energy to heat the inlet air at no additional cost. This is the installation of a gasoline engine with a spark ignition of the incandescent coil in the intake air line, which will receive power from the battery. Such modernization of the system does not require major design changes and significant financial investments.

Unresolved issues remain to assess the effectiveness of the process of heating the air entering the combustion chamber of the engine to create a working mixture.

It should be noted that the optimal heating of the engines is most appropriate to carry out (ie heating the coolant and oil in the engine lubrication system) not to the temperature of the operating thermal mode, but to the temperature that ensures its reliable start.

To select a heater of this type (for a specific engine) determine its heat output, respectively, the size and requirements for starting the engine at low ambient temperatures.

Semiconductor heaters have become quite in demand in recent years. Based on the use of heaters, original devices have been developed that facilitate the ignition of the working mixture of engines with an electronic fuel injection system.

Due to the high requirements for electrical safety, the most appropriate design of the electric heating element are sealed tubular electric heaters. Their high reliability and electrical safety (the ability to provide the required shape of the heater), allow them to be widely used in various designs of electric heaters, Fig. 2 [11].

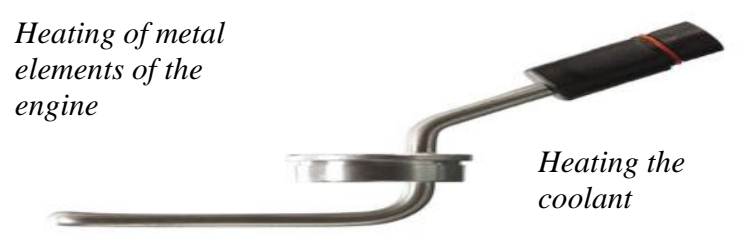

Fig. 2. Safe-Start 000 series engine heater

During the start of a cold engine, only a small percentage of light gasoline fractions evaporate, and fuel that has not evaporated settles on the walls of the intake manifold, creating a fuel film. When it enters the engine cylinders, the process of spraying the spark plug electrodes takes place and the oil film is washed away from the walls of the cylinders.

The maximum complete evaporation of gasoline (at low ambient temperatures) can be achieved using a special gasoline evaporator. It is installed it in the intake systems of the gasoline engine (to heat gasoline to a temperature of $189 \ldots 195^{\circ}$ C), Fig. 4.

The amount of gasoline entering the evaporator is dosed by the control needle of the solenoid fuel valve, provided that all the gasoline evaporates.

In the Fig. 3, shown a diagram of a gasolineevaporator device for starting cold gasoline engines [8-10].

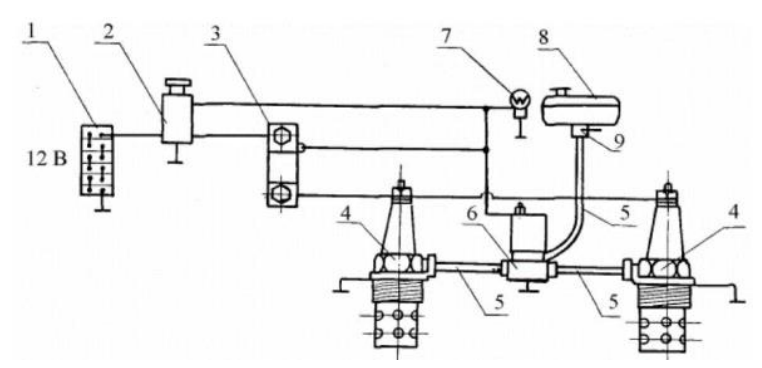

Fig. 3. Scheme of the gasoline electric evaporator device: 1 - rechargeable battery; 2 - threeposition switch; 3 - resistor with thermal relay; 4 - gasoline electric evaporators; 5 gas pipelines; 6 - the electromagnetic fuel valve; 7 - control lamp; 8 - a gas tank with the filter; 9 - faucet

To determine the influence of the intake air temperature on the technical and operational 
parameters of the gasoline engine, it is necessary to establish the physicochemical parameters of volatile fuel (gasoline), and to conduct a thermal calculation of the engine, according to the method [9].

In the Table. 1 presents the physico-chemical parameters of the fuel $[4,9]$.

Table 1 Physico-chemical parameters of volatile fuel

\begin{tabular}{|c|c|c|c|c|}
\hline $\begin{array}{c}\text { Kind } \\
\text { of } \\
\text { fuel }\end{array}$ & $\begin{array}{c}\text { Density } \\
\text { at } 20^{\circ} \mathrm{C}, \\
\mathrm{kg} / \mathrm{m}^{3}\end{array}$ & $\begin{array}{c}\text { Viscosity } \\
\text { at } 40^{\circ} \mathrm{C}, \\
\mathrm{cSt}\end{array}$ & $\begin{array}{c}\text { Octane } \\
\text { number }\end{array}$ & $\begin{array}{c}\text { Lower } \\
\text { burning, } \\
\mathrm{kJ} / \mathrm{kg}\end{array}$ \\
\hline A 92 & 726 & 1.6 & 92 & 44000 \\
\hline
\end{tabular}

The use of thermal calculation makes it possible to establish how the pressure of gases in the engine cylinders changes during the processes of intake, compression, combustion and exhaust gases [9].

To effectively start the gasoline engine at low ambient temperatures, they used and installed a heat-resistant spiral in the intake system of the power supply system. This heating element is connected to the general electrical network of the car and additionally performs the function of excitation of the battery.

In the Figure 4 shown a diagram of the connection of the heating element to the mains of the car.

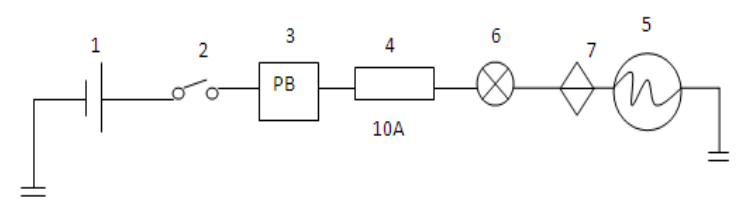

Fig. 4 Wiring diagram of the heating element in the inlet line of the power supply system: 1 rechargeable battery $6 \mathrm{ST} 60 ; 2$ - switch; 3 switching relay; 4 - fuse; 5 - heating spiral; 6 - control lamp; 7 - thermal switch (switches off at $+90^{\circ} \mathrm{C}$ )

The operation of the air heating coil in the inlet line of the supply system of the studied gasoline engine is as follows: before starting the engine (at low ambient temperatures), turn on the switch and voltage from the battery is supplied to the heating coil, heating the housing and the chamber for $15 \mathrm{sec}$. At the same time, the battery is excited, improving its performance. After, the thermal relay works, and the spiral is disconnected from an electric network. The engine is ready to start.

It should be noted that the engine starts smoothly and quickly for $5 \ldots 10$ seconds.

To conduct experimental research, we used laboratory equipment, which includes a stand of point fuel supply and spark supply systems (electronically controlled) of a modern gasoline engine.

This stand of the "Motronic" system is located in the laboratory of the Department of Automobiles and Tractors of the Faculty of Mechanics and power Supply. It consists of: the source of the electric drive of the stand; a modern engine power supply system (which includes all information and transmission mechanisms with electronic control) and measuring fuel volumes for each injector; engine temperature simulator (environment); engine crankshaft speed simulator; all elements of the electronic ignition system.

This stand makes it possible to simulate different modes of engine operation, which are automatically controlled by the on-board electronic control unit, which in turn controls the ignition and power supply systems of the gasoline engine.

All sensors used in the engine with spark ignition are installed on the stand:

- mass air flow meter of mechanical type with built-in air temperature sensor (measures the mass of air used by the engine at a given time). According to its readings, the electronic engine management system supplies the appropriate amount of fuel. We have the opportunity to set (simulate) any air flow on the stand;

- coolant temperature sensor - provides information to the controller about the degree of heating of the engine. With the help of a variable resistor, we can set the temperature from $30^{\circ}$ to $+120^{\circ} \mathrm{C}$.

Figure 5 shows a general view of the stand of the system "Motronic" of the studied engine.

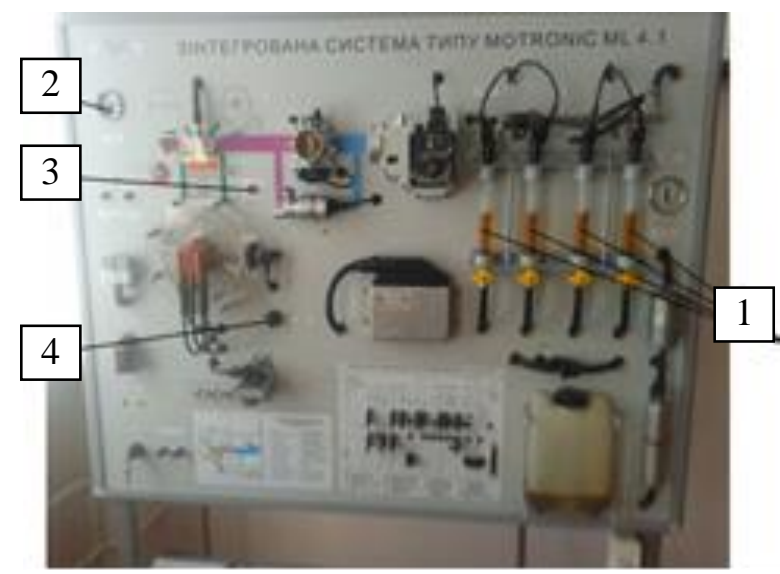

Fig. 5 General view of the stand of the electronic system "Motronic": 1 - measuring tubes; 2 tachometer; 3 - the regulator of a temperature mode of the engine; 4 - crankshaft speed regulator 
According to the determined indicators of heat released after combustion of the working mixture: gasoline A-92 + cold air and gasoline A-92 + warm air in the cylinders of the car engine, heat balance diagrams are constructed, Fig. 6.

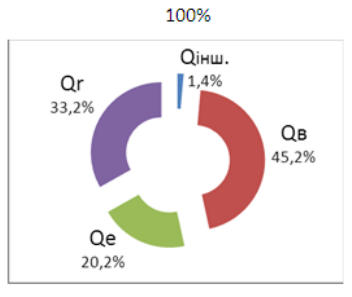

a

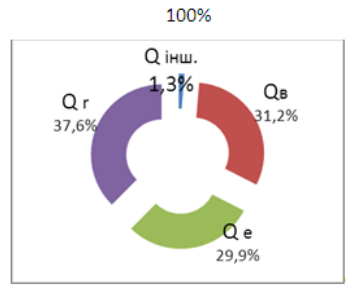

b
Fig. 6. Engine heat balance

After analyzing the heat balance diagrams of the studied gasoline engine, it was found that the effective heat in cold air is $20.2 \%$, and in heated air increased to $29.9 \%$.

This phenomenon is explained by the fact that the effective amount of heat has increased due to the heated air in the intake system.

According to the method of bench research of the gasoline engine with the improved power supply system, the schedule of dependences has been figured out, Fig. 7

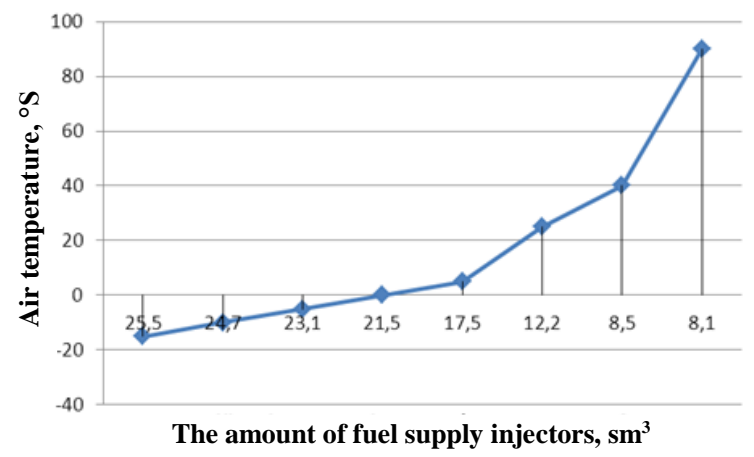

Fig. 7. Graph of fuel consumption at the beginning of starting and warming up the engine in volume
1.61 of the Volkswagen car, depending on the ambient temperature

The graph shows that the operation of the car should begin at a temperature of $+40^{\circ} \mathrm{C}$.

Accordingly, at $-15^{\circ} \mathrm{C}$, fuel consumption increased to $25.5 \mathrm{~cm}^{3}$, compared to $+40^{\circ} \mathrm{C}-8.5 \mathrm{~cm}^{3}$ during $60 \mathrm{~s}$ of engine operation.

Using the stand, Fig. 9, external computer diagnostics of the studied engine and electronic timer found that the warm-up time of the engine using a heating device is significantly reduced.

In the Fig. 8 shows the computer scanning equipment of the engine.
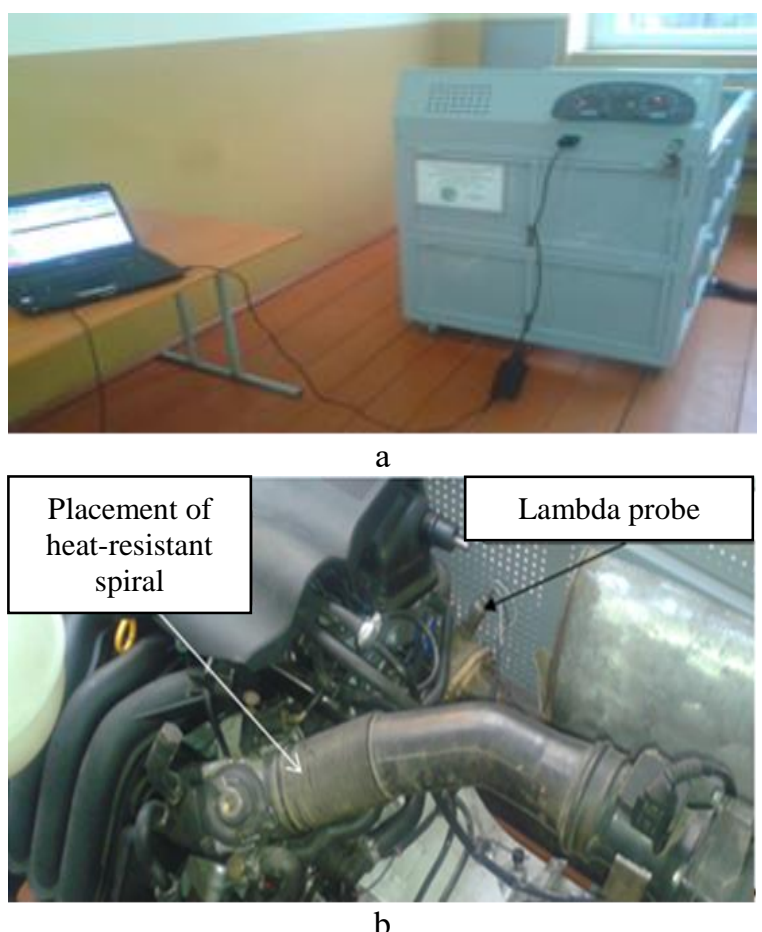

Fig. 8. General view of the stand: a - scanning of the engine; $b$ - placement of the studied elements

In the Fig. 9, shows the results of a computer scan of the engine.

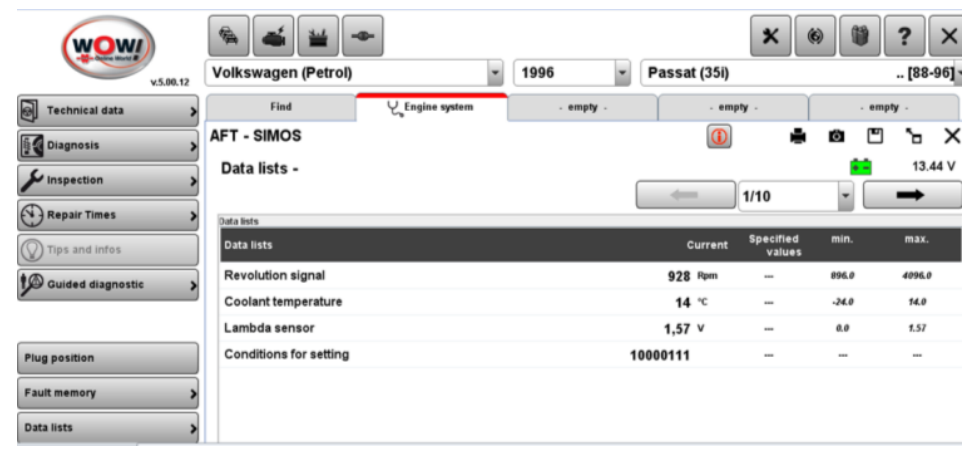




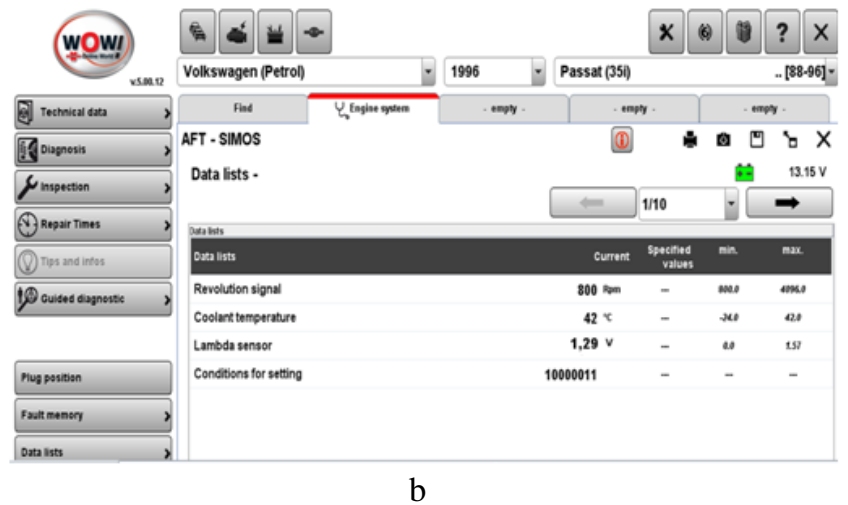

Fig. 9. The results of computer diagnostics of the engine during its warm-up: a - scanned parameters of the studied parameters without a heating device; $b$ - readings with the heating element on

Analyzing the results of computer diagnostics, it can be argued that the use of a heating device (incandescent spiral) improves the completeness of combustion of the working mixture and accelerates the start and warm-up of the engine in low ambient temperatures.

During the operation of the cold engine (for $300 \mathrm{~s}$ ), the temperature of the gasoline engine (with the basic intake system) rose to $14^{\circ} \mathrm{C}$, and with the upgraded - about $42{ }^{\circ} \mathrm{C}$ (operational). Accordingly, the readings of the lambda probe decreased from 1.57 to $1.29 \mathrm{~V}$. The working mixture became more depleted.

\section{Conclusion}

At low ambient temperatures, it is often difficult to start and significantly increase the fuel consumption of gasoline engines.

This upgraded system provides more complete fuel combustion, which in turn contributes to easier start-up and reduced fuel consumption.

The thermal calculation of the gasoline engine showed that in the process of its operation (at low temperatures), the effective heat increased from $20.2 \%$ to $29.9 \%$.

According to the results of bench tests, the duration of engine warm-up at a temperature $\left(-5^{\circ} \mathrm{C}\right)$ is reduced by half.

\section{Acknowledgement}

The authors are thankful to Kharkiv National Automobile and Highway University (KhNAHU, Kharkiv) scientists for their cooperation in completing this study.

\section{Conflict of interests}

The authors declare that there is no conflict of interests regarding the publication of this paper.

\section{References}

1. Варшамов, А. В., Голеншин, В. В., \& Харитонов, М. Ю. (2016). Выбор перспективных схем теплоаккумулирующих систем предпускового прогрева двигателей внутреннего сгорания. Наукові праці. Серія: Техногенна безпека, 280 (268). Varshamov, A. V., Golenshin, V. V., \& Haritonov, M. YU. (2016). Vybor perspektivnyh skhem teploakkumuliruyushchih sistem predpuskovogo progreva dvigatelej vnutrennego sgoraniya. [Selection of promising schemes for heat storage systems for preheating internal combustion engines]. Naukovi praci. Seriya: Tekhnogenna bezpeka, 280 (268). [In Russian].

2. Лісовал А., Нижник М., Вербовський О. (2013) Електронні системи подачі газу в когенераційну установку. Systems and means of motor transport. Selected problems. Seria: Transport, Politechnika Rzesowska, Poland. 245250. Lisoval A., Nizhnik M., Verbovs'kij O. (2013) Elektronni sistemi podachi gazu v kogeneracijnu ustanovku. [Electronic gas supply systems in a cogeneration unit.] Systems and means of motor transport. Selected problems. Seria: Transport, Politechnika Rzesowska, Poland. 245-250. [In Ukrainian].

3. Influence of Ambient Temperature [Электрон. pecypc] Режим доступа: http://manag.com.ua/man-tgx/.

4. Миськів, Т. Г., \& Мурмило, П. П. (2019). Адаптація характеристики сучасного бензинового двигуна до приводу автомобіля. Вісник Національного університету “Львівська політехніка". Серія: Динаміка, міцність та проектування машин і приладів, (910), 94-97. Mis'kiv, T. G., \& Murmilo, P. P. (2019). Adaptaciya harakteristiki suchasnogo benzinovogo dviguna do privodu avtomobilya. [Adaptation of the characteristics of a modern gasoline engine to the drive of the car]. Visnik Nacional'nogo universitetu "L'vivs'ka politekhnika". Seriya: Dinamika, micnist' ta proektuvannya mashin i priladiv, (910), 94-97. [In Ukrainian]. 
5. Підгородецький, Я. І. (2013). Автомобільні транспортні засоби. Основи конструкції. Л.: ЛДУ БЖД. Pidgorodec'kij, YА. I. (2013). Avtomobil'ni transportni zasobi. Osnovi konstrukciï. [Vehicles. Fundamentals of construction.] L.: LDU BZHD. [In Ukrainian].

6. Вербовський, В. С., Грицук, І. В., Адров, Д. С., \& Краснокутська, 3. I. (2013). Дослідження системи передпускового розігріву газового двигуна на основі використання теплового акумулятора 3 теплоакумулюючим матеріалом, що має фазовий перехід. Двигатели внутреннего сгорания, (1), 110-116. Verbovs'kij, V. S., Gricuk, I. V., Adrov, D. S., \& Krasnokuts'ka, Z. I. (2013). Do-slidzhennya sistemi peredpuskovogo rozigrivu gazovogo dviguna na osnovi vikoristannya teplovogo akumulyatora $\mathrm{z}$ teploakumulyuyuchim materialom, shcho ma€ fazovij perekhid. [Investigation of the pre-heating system of a gas engine based on the use of a heat accumulator with a heat-accumulating material having a phase transition]. Dvigateli vnutrennego sgoraniya, (1), 110-116. [In Ukrainian].

7. Halderman, J. D., \& Mitchell, C. D. (2014). Automotive technology. Pearson.

8. Halderman, J. D., \& Linder, J. (2011). Automotive fuel and emissions control systems. Pearson Higher Ed.

9. Шевчук Р.С. (2016) Трактори і автомобілі: основи теорії (питання, завдання та відповіді): навчальний посібник. Львів: Львівський національний аграрний університет, Shevchuk R.S. (2016) Traktori i avtomobili: osnovi teoriï (pitannya, zavdannya ta vidpovidi). [Tractors and cars: basics of theory (questions, tasks and answers)]: navchal'nij posibnik. L'viv: L'vivs'kij nacional'nij agrarnij universitet, [In Ukrainian].

10. Александров В.Д., Гутаревич Ю.Ф., Грицук I.В. (2014) Теплові акумулятори фазового переходу для транспортних засобів: параметри робочих процесів - монографія - Донецьк: Вид-во «Ноулідж». Aleksandrov V.D., Gutarevich YU.F., Gricuk I.V. (2014) Teplovi akumulyatori fazovogo perekhodu dlya transportnih zasobiv.: parametri robochih procesiv - monografiya [Phase transition heat accumulators for vehicles: parameters of work processes - monograph]. Donec'k: Vid-vo «Noulidzh». [In Ukrainian].

11. Адров, Д. С., Грицук, І. В., Прилепський, Ю. В., \& Дорошко, В. I. (2011). Тепловий акумулятор як засіб підвищення ефективності пуску стаціонарного двигуна в умовах низьких температур. Сборник научных трудов Донецкого института железнодорожного транспорта, (27). Adrov, D. S., Gricuk, I. V., Prileps'kij, YU. V., \& Doroshko, V. I. (2011). Teplovij akumulyator yak zasib pidvishchennya efektivnosti pusku stacionarnogo dviguna $\mathrm{V}$ umovah niz'kih temperatur. [Heat accumulator as a means of increasing the efficiency of starting a stationary engine at low temperatures]. Sbornik nauchnyh trudov Doneckogo instituta zheleznodorozhnogo transporta, (27). [In Ukrainian].

12. Robert Bosch GmbH (2013) Датчики в автомобиле. Москва: "За рулем". Robert Bosch GmbH (2013). Datchiki v avtomobile. [Car sensors]. Moskva: "Za rulem". [In Russian].

13. Robert Bosch GmbH. (2012) Автомобильный справочник. 3-е изд. [Automotive Handbook. 3rd ed] Москва: За рулем. Robert Bosch GmbH. (2012) Avtomobil'nyj spravochnik. 3-e izd. Moskva: Za rulem. [In Russian].

Magats Myron ${ }^{1}$ Ph.D., Assoc. Prof. Department automobiles and tractors,

mironmahats@gmail.com, tel. +38 0671726002,

ORCID: 0000-0001-5339-139X

Goshko Zenoviy ${ }^{1}$ Ph.D., Assoc.Prof. Department agricultural machinery,

zdenuk@gmail.com, tel. +38 0936884025,

ORCID: 0000-0003-0383-8960

Vagula Yuriy ${ }^{1}$ teacher-methodologist of ecologicallogical professional college of LNAU,

vagyla2020 @ gmail.com, tel. +38 0683546605,

ORCID: 0000-0003-0867-335X

Uzhva Anatolii², DSci (Engineering), Assoc. Prof.

Department of automobiles,

Uzhva_av@ukr.net, tel. +38-067-422-31-97,

ORCID: 0000-0002-1615-8019

${ }^{1}$ Lviv National Agrarian University, 80381, Ukraine, Dublyany, street V. Velykoho 1, Zhovkva district, Lviv region.

${ }^{2}$ Kharkiv National Automobile and Highway University Yaroslava Mudrogo str., 25, Kharkiv, Ukraine, 61002

\section{Дослідження модернізованої впускної системи бензинового двигуна}

Анотація. Проблема. В останні роки в Украӥні спостерігається різке зниження температури навколишнього середовища, особливо взимку. Відповідно, це негативно позначається на роботі двигунів автомобілів (утруднений запуск і тривалий прогрів), оскільки левова частка автомобілів приватного сектора паркується на відкритих майданчиках і піддається різким перепадам температури $і$ вологості. Тому для часткового вирішення иієї проблеми наша увага була зосереджена на повітропроводах впускної системи бензинового двигуна, оскільки ия система легкодоступна і не потребує істотних змін конструкиї для своєї модернізації. Мета. Забезпечити легкість запуску бензинового двигуна $і$ скоротити час на прогрівання. Методологія. Експлуатація автомобіля в умовах знижених температур, істотно сприяє погіршенню його паливної економії. В основі такого негативного процесу витрати палива лежить неповне згоряння робочої суміші. A ие погіршення розпилення $і$ випаровування палива і збільшення тривалості прогріву двигуна. При 
таких низьких температурах навколишнього середовища ефективна робота автомобіля в гаражі значною мірою залежить від способу його приготування (який повинен при мінімальних витратах паливно-енергетичних ресурсів забезпечити швидкий і надійний запуск двигуна і прискорений прогрів). Ми вирішили отримати теплову енергію для нагріву вхідного повітря без додаткових витрат. Це установка бензинового двигуна з іскровим запалюванням котушки розжарювання у впускному повітропроводі, який буде отримувати живлення від акумулятора. Така модернізація системи не потребує значних змін конструкиії та значних фінансових вкладень Невиріменими залишаються питання оцінки ефективності процесу нагріву повітря, щзо надходить у камеру згоряння двигуна для створення робочої сумімі. Слід зазначити, щзо оптимальний прогрів двигунів найбільи доцільно здійснювати (тобто підігрів охолоджуючої рідини і масла в системі змащення двигуна) не до температури робочого теплового режиму, а до температури, яка забезпечує його надійний запуск. Результати. Представлена схема підключення підігрівача всмоктуваного повітря в бортову електричну мережу автомобіля. Отримано результати теплового балансу досліджуваного бензинового двигуна (з використанням холодного та нагрітого повітряного потоку) під час його нагрівання. Встановлено оптимальну температуру прогрітого двигуна, при якій можлива подальша економна експлуатаџія автомобіля. Оригінальність. Цей спіральний обігрівач вперше використовувався для підігріву заряду впускного повітря під час пуску та прогріву бензинового двигуна. Практична цінність. Розроблене опалювальне обладнання можна використовувати як для бензинових, так $і$ для дизельних двигунів внутрішнього згоряння. Його слід вмикати тільки під час запуску і прогріву двигуна.

Ключові слова: спіраль розжарювання, впускна система, пускові характеристики, час прогріву двигуна, витрата палива.

Магац Мирон Іванович ${ }^{1}$, к.т.н., доцент. кафедри. автомобілів та тракторів, mironmahats@gmail.com, тел. +38 0671726002, ORCID: 0000-0001-5339-139X

Гошко Зиновій Орестович ${ }^{1}$, к.т.н., доц. кафедри. сільськогосподарської техніки, zdenuk@gmail.com, тел. +38 0936884025,

ORCID: 0000-0003-0383-8960

Вагула Юрій Игорович ${ }^{1}$, викладач-методист екологічного професійного коледжу ЛНАУ, vagyla2020@ gmail.com тел. +38 0683546605, ORCID: 0000-0003-0867-335X

Ужва Анатолій Вікторович, к.т.н., доцент. кафедри автомобілів ім. А.Б. Гредескула, Uzhva_av@ukr.net, tel. +38-067-422-31-97, ORCID: 0000-0002-1615-8019

${ }^{1}$ Львівський національний аграрний університет, 80381, Україна, г. Дубляни, вул. В. Великого 1, Жовковського р-ну, Львівської обл.

${ }^{2}$ Харківський національний автомобільнодорожній університет, вул. Ярослава Мудрого, 25, м. Харків, Україна, 61002 